AGREGAT: Jurnal Ekonomi dan Bisnis

Vol. 1, No. 1, Maret 2017

http://journal.uhamka.ac.id/index.php/agregat

p-ISSN: 2549-5658 e-ISSN: 2549-7243

DOI: $10.22236 /$ agregat_vol1/is1pp38-58

Hal 38-58

\title{
KINERJA BUMN DI INDONESIA: KOMPENSASI EKSEKUTIF, LEVERAGE, SIZE, DAN KEPEMILIKAN MANAJERIAL
}

\author{
Hesty Erviani Zulaecha \\ Mukhmainna Syamsuddin \\ Universitas Muhammadiyah Tangerang \\ Email: hesty@gmail.com
}

Diterima: 4 Januari 2017; Direvisi: 8 Februari 2017; Disetujui: 26 Februari 2017

\begin{abstract}
The purpose of this study to determine the influence of executive compensation, leverage, company size and managerial ownership on the performance of state-owned companies in Indonesia. Executive compensation is seen from the amount of compensation granted to directors, leverage is measured by the ratio of DER, the size of the firm views of total assets, managerial ownership seen from the percentage of managerial ownership. The company's performance using ratios Return On Equity. This study used a sample of state-owned enterprises listed on the Stock Exchange during the years 2012-2015 by using purposive sampling method. The data used were obtained from the annual financial statements listed in the Indonesia Stock Exchange. There are 19 companies that meet the criteria. The analytical method used in this study is a multivariate regression. The results showed that the executive compensation and leverage have significant influence while the size of the company and managerial ownership has a weak influence on the performance of state-owned companies in Indonesia.
\end{abstract}

Keywords: Executive compensation, leverage, company size, Managerial Ownership.

\begin{abstract}
Abstrak
Tujuan penelitian ini untuk mengetahui pengaruh kompensasi eksekutif, leverage, ukuran perusahaan dan kepemilikan manajerial terhadap kinerja perusahaan BUMN di Indonesia. Kompensasi eksekutif dilihat dari jumlah nilai kompensasi yang diberikan terhadap direksi, leverage diukur dengan rasio DER, ukuran perusahaan dilihat dari total aset, kepemilikan manajerial dilihat dari persentase kepemilikan saham manajerial. Kinerja perusahaan menggunakan rasio Return On Equity. Penelitian ini menggunakan sampel perusahaan BUMN yang terdaftar di BEI selama tahun 2012-2015 dengan menggunakan metode purposive sampling. Data yang digunakan diperoleh dari laporan tahunan dan keuangan yang terdaftar di Bursa Efek Indonesia. Terdapat 19 perusahaan yang memenuhi kriteria. Metode analisis yang digunakan dalam penelitian ini adalah multivariate regression.Hasil penelitian menunjukkan bahwa kompensasi eksekutif dan leverage mempunyai pengaruh signifikan sedangkan ukuran perusahaan dan kepemilikan manajerial memiliki pengaruh yang lemah terhadap kinerja perusahaan BUMN di Indonesia.
\end{abstract}

Kata Kunci: Kompensasi eksekutif, Leverage, Ukuran Perusahaan, Kepemilikan Manajerial. 


\section{PENDAHULUAN}

Penelitian ini difokuskan terhadap perusahaan BUMN dikarenakan berdasarkan Forbes Global 2000 List, yang dirilis oleh majalah Forbes, mencatat 10 perusahaan Indonesia ke dalam list perusahaan paling sukses di dunia pada tahun 2011 (Prihatiningtyas, 2012).

Dari 10 perusahaan tersebut, enam diantaranya merupakan perusahaan BUMN. Tujuan penelitian ini adalah menguji pengaruh dari kompensasi eksekutif, leverage, ukuran oerusahaan dan kepemilikan manajerial terhadap kinerja Perusahaan BUMN di Indonesia. Kinerja keuangan perusahaan merupakan prestasi kerja yang telah dicapai oleh perusahaan dalam suatu periode tertentu dan tertuang dalam laporan keuangan perusahaan yang bersangkutan (Anggitasari dan Mutmainah, 2012; Horne, 2012). Kinerja keuangan juga akan memberikan gambaran efisiensi atas pengunaan dana mengenai hasil akan memperoleh keuntungan dapat dilihat setelah membandingkan pendapatan bersih setelah pajak. Kinerja keuangan merupakan kegiatan perusahaan yang ditujukan untuk mendapatkan dan menggunakan modal dengan cara yang efektif dan efisien (Irham, 2011).
Kinerja perusahaan yang dapat dilihat dari laporan keuangan merupakan hasil pertanggungjawaban dan prestasi dari pihak manajemen yang merupakan pihak yang diberikan kepercayaan untuk mengelola perusahaan dengan sumber daya yang terbatas dari pihak pemegang saham. Di dalam teori keagenan (Jensen dan Meckling, 1976) dijelaskan bahwa pada sebuah perusahaan terdapat dua pihak yang saling berinteraksi, yaitu pemilik perusahaan (pemegang saham) sebagai pihak principal dan manajer perusahaan sebagai pihak agen. Pemegang saham disebut sebagai prinsipal, sedangkan manajer, orang yang diberi kewenangan oleh pemegang saham untuk menjalankan perusahaan, disebut agen.

Teori keagenan menjelaskan bahwa hubungan agen-prinsipal sangat tergantung pada penilaian prinsipal tentang kinerja agen. Pihak manajer yang memang merupakan pihak yang dipercayakan untuk memberikan kekayaan kepada pihak principal, pada teori agen ini dinyatakan bahwa tujuan pihak manajemen mengelola perusahaan tidak bertujuan memberikan keuntungan kepada pihak principal, namun dengan tujuan memberikan keuntungan bagi diri 
42 AGREGAT: Jurnal Ekonomi dan Bisnis

Vol. 1 No 1 Maret 2017

http://journal.uhamka.ac.id/index.php/agregat

DOI: 10.22236/agregat_vol1/is1pp38-58

mereka sendiri. Jika pihak manajemen menerima penghargaan ataupun kompensasi yang memadai maka diharapkan dapat memberikan keuntungan bagi pihak principal.

Namun disisi lain, pihak principal akan membatasi penggunaaan dana yang ada dalam perusahaan dengan cara dana perusahaaan berasal dari pinjaman dan ini merupakan salah satu bentuk biaya monitoring yang dilakukan oleh pihak principal terhadap pihak agen.

Menurut Otoritas Jasa Keuangan (2014), upaya pengawasan terhadap perusahaan pada sektor keuangan ini dapat diwujudkan dengan adanya implementasi praktik tata kelola perusahaan atau Good Corporate Governance (GCG). Dengan pengawasan terhadap GCG yang diterapkan pada perusahaan diharapkan penerapan GCG tersebut diperbaiki dan ditingkatkan agar dapat meningkatkan kinerja perusahaan baik secara finansial maupun operasional (Otoritas Jasa Keuangan, 2014).

Erkens et. al. (2012), menunjukkan bahwa corporate governance perusahaan memiliki dampak penting terhadap kinerja perusahaan selama krisis melalui keputusan manajemen perusahaan yang berani mengambil risiko dan pembiayaan kebijakan. Blockholders ownership adalah pemegang saham dalam porsi besar (Lorett,N. Baryah, 2014). Sementara menurut Agrawal dan Knoeber (1996) kepemilikan saham dalam jumlah besar terdiri atas: kepemilikan saham oleh manajerial, kepemilikan saham oleh institusional dan kepemilikan saham oleh individu (blockholders ownership). Menurut Kim dan Lee (2003) dalam Maghdalena, 2014), blokcholders ownership adalah kepemilikan saham oleh individu dan perusahaan, dimana kepemilikannya paling sedikit 5\% dari jumlah saham yang beredar. Blockholders ownership memiliki peranan penting dalam pengelolaan perusahaan karena blockholders ownership dapat mengintervensi manajemen perusahaan dengan suara yang dimilikinya dalam rangka menentukan kebijakan yang akan dilakukan perusahaan untuk meningkatkan kinerja perusahaan.

Peningkatan kepemilikan manajerial membantu untuk menghubungkan kepentingan pihak internal dan pemegang saham, dan mengarah ke pengambilan keputusan yang lebih baik dan meningkatnya nilai perusahaan. Dengan 
demikian, aktivitas perusahaan dapat rangka meningkatkan keuntungan diawasi melalui kepemilikan manajerial (Singapurwoko, 2011). yang besar (Endraswati, 2012).

Perusahaan besar lebih cenderung

Untuk meningkatkan kinerja memanfaatkan sumber daya yang perusahaan dalam sisi modal perusahaan dimilikinya daripada menggunakan menggunakan rasio hutang, Menurut pembiayaan yang berasal dari hutang. Harahap (1997) dalam Endah (2014) Perusahaan besar akan menjadi sorotan Rasio leverage merupakan rasio yang pemerintah, sehingga akan menimbulkan menghubungkan antara hutang perusahaan kecenderungan bagi para manajer terhadap modal maupun asset. Rasio ini dapat melihat seberapa jauh perusahaan dibiayai oleh hutang atau pihak luar dengan kemampuan perusahaan yang digambarkan oleh modal.Perusahaan yang relatif besar cenderung akan perusahaan untuk berlaku agresif atau patuh (Maria dan Kurniasih, 2013). Penggunaan financial leverage tersebut pada kenyataannya memberikan pengaruh terhadap profitabilitas perusahaan, salah satunya ditunjukkan dengan besarnya menggunakan dana eksternal yang besar pula karena dana yang dibutuhkan semakin meningkat seiring dengan pertumbuhan perusahaan (Ba-Abbad dan Zaluki, 2012).

Perusahaan dengan pertumbuhan yang tinggi tentunya memerlukan dana yang tidak sedikit untuk membiayai aktivitas operasional perusahaannya. pengembalian atau return yang akan diterima oleh pemilik perusahaan melalui Return On Equity (ROE) perusahaan (Ritonga, Kertahadi, dan Rahayu: 2014).

Beberapa penelitian serupa menjelaskan bahwa menurut penelitian di tahun 2012 Nurfitriana meneliti pengaruh ukuran perusahaan, aktivitas dan leverage terhadap profitabilitas. Hasil penelitian Kebutuhan dana tersebut dapat dipenuhi menunjukkan bahwa ketiga variabel salah satunya dari sumber dana eksternal mempunya pengaruh yang signifikan perusahaan, yaitu dengan hutang. positif terhadap profitabilitas.Penelitian Leverage adalah salah satu faktor penting Agus Wibowo dan Sri Wartini (2012), yang memengaruhi profitabilitas karena yang berjudul Efisiensi Modal Kerja, leverage bisa digunakan perusahaan untuk Likuiditas dan Leverage Terhadap meningkatkan modal perusahaan dalam Profitabilitas Pada Perusahaan 
44 AGREGAT: Jurnal Ekonomi dan Bisnis

Vol. 1 No 1 Maret 2017

http://journal.uhamka.ac.id/index.php/agregat

DOI: 10.22236/agregat_vol1/is1pp38-58

Manufaktur Di BEI, menyatakan bahwa efisiensi modal kerja berpengaruh signifikan terhadap profitabilitas sedangkan likuiditas dan leverage tidak berpengaruh.Rosyadah dkk., (2013) Mahmoudi (2014) dan Khan dan Khokhar (2015) juga menemukan bahwaleverage berpengaruh negatif dan signifikan terhadap profitabilitas perusahaan.

Penelitian Agus Wibowo dan Sri Wartini (2012), yang berjudul Efisiensi Modal Kerja, Likuiditas dan Leverage Terhadap Profitabilitas Pada Perusahaan Munufaktur Di BEI, menyatakan bahwa efisiensi modal kerja berpengaruh signifikan terhadap profitabilitas sedangkan likuiditas dan leverage tidak berpengaruh. Persamaan penelitian yang dilakukan Wright et a. (2009) menemukan bahwa ukuran perusahaan berpengaruh positif terhadap kinerja. Penelitian yang dilakukan oleh Gill dan Obradovich (2012) yang menyatakan bahwa ukuran perusahaan berpengaruh positif dan signifikan terhadap nilai perusahaan.

Namun penelitian Talebria et al. (2010) dan Fachrudin (2011) menemukan bahwa tidak terdapat pengaruh ukuran perusahaan terhadap kinerja perusahaan karena ukuran perusahaan tidak menjamin bahwa perusahaan yang lebih besar akan menjamin kinerja yang baik. Terdapat ketidak konsisten penelitian tersebut menjadikan penelitian meneliti kembali atas judul yang akan diambil penelitian selanjutnya. Penelitian Permanasari (2010), Ulfah (2011) dan Rachmad (2012) menyimpulkan kepemilikan manajerial tidak berpengaruh pada kinerja perusahaan. Penelitian Puteri (2012) menemukan bahwa kepemilikan manajerial berpengaruh negatif pada kinerja perusahaan.

Penelitian ini memberikan beberapa kontribusi literature. Pertama, penelitian ini memberikan bukti empiris peranan kompensasi yang diberikan pada pihak eksekutif, leverage, size serta kepemilikan manajerial terhadap kinerja perusahaan BUMN. Penelitian ini memberikan tambahan literatur sebelumnya yang hanya membahas mengenai kompensasi manajerial yang dikaitkan dengan kinerja perusahaan BUMN di Indonesia. Kedua, penelitian ini memberikan bukti bahwa leverage berperan penting dalam menigkatkan kinerja perusahaan. Hal ini sejalan dengan teori agensi yang menyatakan bahwa salah satu cara untuk mengurangi biaya agensi adalah dengan 
melakukan pendanaan dari pihak ketiga. Selain kontribusi literature, penelitian ini memberikan kontribusi praktis, yaitu besar kecilnya kompensasi yang diberikan kepada pihak manajerial memberikan rangsangan untuk melakukan yang terbaik bagi perusahaan sehingga hal ini harus menjadi perhatian bagi para investor.

\section{Pengaruh Kompensasi Eksekutif terhadap Kinerja Perusahaan.}

Kompensasi merupakan segala sesuatu yang diberikan oleh perusahaan sebagai balas jasa atau imbalan atas kinerja yang dihasilkan untuk kepentingan suatu perusahaan khususnya terhadap eksekutif (Dessler, 1997) dalam Mayangsari (2015). Menurut Arifah (2012) Agency Theory dalam kompensasi eksekutif terdapat adanya benturan kepentingan, masing-masing pihak ingin memaksimalkan kepentingannya.

Benturan kepentingan yang sangat terlihat terjadi antara pihak pemilik perusahaan (prinsipal) dan pihak manajemen (agen). Prinsipal mengharapkan pengelolaan perusahaan sebaik mungkin untuk menghasilkan laba dan agen menginginkan adanya reward atas prestasinya.

Dari hasil teori tersebut terdapat hubungan antara kompensasi eksekutif terhadap kinerja perusahaan, semakin baik target dan hasil yang diperoleh perusahaan (kinerja perusahaan) yang dihasilkan oleh pihak-pihak eksekutif akan menuntut imbalan yang sesuai dengan kerja keras yang sudah dilaksanakan seiring dengan baiknya perkembangan kinerja perusahaan semakin besar tingkat penghargaan yang harus dikeluarkan oleh perusahaan.

Pendapat dan teori diatas sesuai dengan kajian teoritis yang termuat dalam media cetak Infobank menyimpulkan bahwa kompensasi yang diberikan oleh pemilik perusahaan telahsebanding dengan kinerja yang dilakukan oleh para eksekutifnya (Sari dan Harto, 2014).

H1: Kompensasi berpengaruh signifikan terhadap kinerja perusahaan.

\section{Pengaruh Kepemilikan Manajerial Terhadap Kinerja Perusahaan \\ Kepemilikan manajerial adalah} kepemilikan saham perusahaan oleh pihak manajemen atas presentasi saham yang dimiliki oleh eksekutif dan kreditur. Besar kecilnya jumlah kepemilikan manajerial dalam perusahaan dapat mengindikasi kesamaan kepentingan antara manajemen dan pemegang sahamMenurut Putra dan Paulinda (2013). Kepemilikan manajerial adalah salah satu dari coprorate governance. 
46 AGREGAT: Jurnal Ekonomi dan Bisnis

Vol. 1 No 1 Maret 2017

http://journal.uhamka.ac.id/index.php/agregat

DOI: 10.22236/agregat_vol1/is1pp38-58

Mekanisme corporate governance menjadi pertimbangan dalam pemisahan konflik yang terdapat didalam perusahaan antara pihak prinsipal dan pihak agen sebagaimana disebutkan dalam teori Jensen dan Meckling (1976) dalam Armini dan Wirama (2015) menyatakan semakin tinggi kepemilikansaham oleh manajemen maka semakin kuat kecenderungan manajemen untuk mengoptimalkan penggunaan sumber daya sehingga meningkatkan kinerja perusahaan.

Kepemilikan manajerial terhadap kinerja perusahaan menjadi pemisahaan konflik yang terdapat didalam perusahan dengan kepemilikan manajerial mampu menjadi mekanisme corporate governance yang dapat mengurangi ketidakselarasan kepentingan antara manajemen dengan pemilik atau pemegang saham dengan adanya pemisahan ini antara manajer dan pemilik perusahaan dapat diselaraskan terkait tujuan perusahaan yang ingin dicapai, dengan kepemilikan manajerial berpengaruh signifikan terhadap kinerja perusahaan.

Pendapat diatas didukung dengan penelitian Hermalin dan Weisbach (1991) dalam wiranata dan nugrahanti (2013) meneliti pengaruh kepemilikan manajerial. Hasil penelitian menunjukkan bahwa kepemilikan manajerial berpengaruh positif terhadap kinerja keuangan perusahaan.

H2 = Kepemilikan manajerial berpengaruh signifikan terhadap kinerja perusahaan.

\section{Pengaruh Leverage Terhadap Kinerja Perusahaan}

Leverage adalah penggunaan aset dan sumber dana (sources of funds) oleh perusahaan yang memiliki biaya tetap (beban tetap) dengan maksud agar meningkatkan keuntungan potensial pemegang saham (Sartono, 2010). Menurut penelitian terdapat hubungan antara teori dengan penelitian Foster (1986) dalam Agustia mengungkapkan bahwa terdapat hubungan antara rasio leverage dengan return perusahaan. Artinya hutang dapat digunakan untuk memprediksi keuntungan yang kemungkinan bisa diperoleh bagi investor jika berinvestasi pada suatu perusahaan. Jensen and Meckling (1976) dalam Agustia (2013) berargumen tentang moral hazard untuk menjelaskan agency cost of debt, bahwa level hutang tinggi 
akan menyebabkan perusahaan untuk memilih pada proyek-proyek investasi berisiko secara berlebihan.

Rasio Leverage dalam perusahaan dibutuhkan dikarenakan dengan dengan leverage merupakan dapat menghubungkan antara hutang perusahaan terhadap modal. Pemakaian modal atas pinjaman hutang yang dapat dimanfaatkan dengan semaksimal mungkin untuk kegiatan operasional ini dapat meningkatkan perolehan laba perusahaan dengan ini dapat tercipta kinerja perusahaan yang baik.

Pendapat diatas didukung dengan penelitian (Ritonga, Kertahadi, dan Rahayu: 2014) yang menyatakan bahwa penggunaan financial leverage tersebut pada kenyataannya memberikan pengaruh terhadap profitabilitas perusahaan, salah satunya ditunjukkan dengan besarnya pengembalian atau returnyang akan diterima oleh pemilik perusahaan melalui Return On Equity (ROE) perusahaan. H3 = Leverage berpengaruh signifikan terhadap kinerja perusahaan.

\section{Pengaruh Ukuran Perusahaan Terhadap Kinerja Keuangan}

Ukuran perusahaan merupakan suatu pengklasifikasian sebuah perusahaan berdasarkan jumlah aset yang dimilikinya.
Aset dinilai memiliki tingkat kestabilan yang cukup berkesinambungan (Maria dan Kurniasih, 2013). Darmawati (2004) dalam Maria dan Kurniasih, 2013) menyatakan bahwa perusahaan besar pada dasarnya memiliki kekuatan finansial yang lebih besar dalam menunjang kinerja, tetapi disisi lain, perusahaan dihadapkan pada masalah keagenan yang lebih besar. Dengan penelitian diatas dapat disimpulkan bahwa ukuran perusahaan berpengaruh terhadap perusahaan. Perusahaan yang besar degan aset besar biasanya akan mendapatkan perhatian lebih dari pihak luar dengan itu perusahaan lebih berhati-hati untuk melakukan pelaporan keuangan, ini demi tercerminya stabilitas kinerja perusahaan.

Daya tarik perusahaan terhadap pihak luar/ investor selain dengan laporan keuangan salah satu indikatornya adalah dapat dilihat dari seberapa besar ukuran perusahaan, semakin besar perusahaan dilihat dari jumlah asset yang dimilikinya ini dikatakan dapat berpengaruh terhadap tujuan perusahaan, dikarenakan semakin besarnya asset yang dimiliki perusahaan pemanfaatan atas asset tersebut semakin tinggi dan dapat menghasilkan pengembaliann yang tinggi atas penggunaan asset tersebut, dengan itu 
48 AGREGAT: Jurnal Ekonomi dan Bisnis

Vol. 1 No 1 Maret 2017

http://journal.uhamka.ac.id/index.php/agregat

DOI: 10.22236/agregat_vol1/is1pp38-58

ukuran perusahaan berpengaruh terhadap instrumen dikatakan valid jika istrumen kinerja perusahaan.

ini mampu mengukur apa saja yang

Pendapat tersebut diperkuat dengan hendak diukurnya, mampu

Hesti (2011) dan Uyun (2011) mengungkapkan apa yang di inginkan. menemukan bukti bahwa ukuran Pengukuran validitas dilakukan dengan perusahaan berpengaruh positif signifikan mencari besarnya korelasi antara skor terhadap kinerja keuangan perusahaan.

butir-butir pertanyaan dalam kuesioner H4 = Ukuran perusahaan berpengaruh signifikan terhadap kinerja perusahaan.

\section{METODE PENELITIAN}

Reponden penelitian ini meliputi seluruh karyawan karyawan tetap, kecuali direktur dan wakil direktur. Dengan demikian penelitian ini mengambil responden seluruh populasi karyawan perusahaan, dan sehinggga tidak dilakukan sampling. Hal tersebut dikarenakan jumlah karyawan perusahan tersebut tidak terlalu besar. Karyawan tetap perusahaan berjumlah 35 orang.

Suatu alat ukur atau istrumen pengumpul data harus memenuhi syarat validitas dan reliabilitas, sehingga data yang diperoleh dari pengukuran jika diolah tidak memberikan hasil yang menyesatkan. Validitas merupakan tingkat kemampuan suatu instrumen untuk mengungkapakan suatu yang menjadi sasaran pokok pengukuran yang dilakukan dengan instrumen tersebut. Suatu dengan total skor variabel. Selanjutnya nilai korelasi ini dibandingkan dengan nilai korelasi menurut tabel (dengan $\alpha=5 \%$ ). Apabila nilai korelasi hasil perhitungan melebihi nilai korelasi tabel, maka butir-butir pertanyaan tersebut dikatakan valid. Pengujian validitas dilakukan dengan menggunakan korelasi product moment berdasar rumusan berikut.

$$
\begin{aligned}
& \text { rxy : koefisien korelasi } \\
& \mathrm{n}: \text { jumlah observasi }
\end{aligned}
$$

Sementara itu, realibilitas menunjukkan sejauh mana suatu instrumen dapat memberikan hasil pengukuran yang konsisten, apabila pengukuran dilakukan berulang- ulang. Pengujian reliabilitas ini hanya dilakukan terhadap butir-butir yang valid, yang diperoleh melalui uji validitas. Selanjutnya Nunnaly, 1978 dalam Ghozali (2001) menyatakan bahwa uji reliabilitas dilakukan dengan cara menghitung 
Cronbach Alpha dari masing-masing instrumen yang dipakai dan dikatakan reliabel jika memiliki Cronbach Alpha lebih dari 0,6. Perhitungan Cronbach Alpha dilakukan berdasar rumusan berikut

$$
r_{t t}=\left[\frac{k}{k-1}\right]\left[1-\frac{\sum \sigma_{b}^{2}}{\sigma_{1}^{2}}\right]
$$

Keterangan:

$$
\begin{array}{ll}
\mathrm{r}_{\mathrm{tt}} & \text { : Koefisien cronbach alpha } \\
\mathrm{k} & : \text { jumlah pecahan } \\
\sum \sigma_{b}^{2} & : \text { total dari varian masing-masing }
\end{array}
$$
pecahan

$\sigma_{1}^{2} \quad$ : varian dari total skor

Secara umum data penelitian merupakan data primer yang mencakup data , komitmen, kompensasi, dan prestasi kerja. Data primer tersebut diperoleh melaui wawancara dengan mengajukan pertanyaan secara langsung kepada karyawan PT. Somit Karsa Trinergi baik karyawan penyebaran kuesioner (daftar pertanyaan) kepada para karyawan tersebut. Kuesioner dirancang berdasar Skala Likert, dengan butir-butir pernyataan tentang, komitmen, kompensasi, dan prestasi kerja. Penentuan skor tiap-tiap butir pertanyaan didasarkan pada skala interval 1 sampai dengan 4, dengan kriteria berikut.

a. Skor 1 = sangat tidak setuju b. Skor 2 = tidak setuju

c. Skor 3 = setuju

d. Skor 4 = sangat setuju.

Di samping itu, penelitian ini juga menggunakan data sekunder yang berupa laporan-laporan dan publikasi dari Perusahaan. Penggunaan data sekunder dimaksudkan untuk menjelaskan informasi tentang perusahaan yang tidak dapat dicakup melalui data primer.

Penelitian ini akan menggunakan alat analisis regresi berganda. Analisis regresi akan mengkaji ada tidaknya pengaruh variabel bebas (independent variable) terhadap variabel tidak bebas (dependent variable) serta besarnya pengaruh tersebut. Dalam penelitian ini variabel tidak bebas adalah prestasi kerja, sedangkan variabel-variabel bebas meliputi, komitmen, dan kompensasi. Selanjutnya model regresi dituangkan dalam persamaan berikut.

Keterangan : Y adalah prestasi kerja $\mathrm{X} 1$ adalah

X2 adalah komitmen

X3 adalah kompensasi

e adalah residual

Selanjutnya persamaan di atas akan diestimasi dengan ordinary least square (OLS). Keandalan parameter-parameter yang diestimasi dapat dilihat melalui 2 
50 AGREGAT: Jurnal Ekonomi dan Bisnis

Vol. 1 No 1 Maret 2017

http://journal.uhamka.ac.id/index.php/agregat

DOI: 10.22236/agregat_vol1/is1pp38-58

(dua) kriteria yaitu pengujian signifikasi parameter secara individual (uji t) dan uji signifikasi parameter secara bersamasama (uji F). Model regresi yang baik adalah model regresi yang ditandai dengan relatif besarnya variasi variabel dependen yang dapat dijelaskan oleh

\section{HASIL DAN PEMBAHASAN}

PT Somit Karsa Trinergi adalah perusahaan otomatisasi yang didirikan pada tahun 1996. perusahaan yang beralamat di Jakarta timur ini adalah sebuah perusahaan yang menyediakan proses kontrol instrumentasi, sistem integrasi dan melayani kebutuhan industri secara umum.

1. Bidang industri yang menjadi konsumen perusahaan ini adalah:

a. Oil \& Gas Industry.

b. Cement Industry.

c. Electricity \& Thermal Energy.

d. Water \& Waste Water Treatment.

2. Lingkup pelayanan dari perusahaan ini adalah:
a. Engineering.
b. Procurement.
c. Instrument \& Control Construction.
d. System Design.
e. System Integration.
f. Panel Assembly.

variasi variabel-varabel independen. Dengan kata lain model yang memiliki nilai R2 relatif tinggi (Goodness of Fit). Di samping itu model regresi terbebas dari pelanggaran asumsi klasik yang meliputi heteroskedastisitas, autokorelasi dan multikolinieritas.

g. Field Instrument Supply.

h. Calibration.

i. Training.

j. Maintennance Services.

Perusahaan ini mempunyai beberapa divisi yang mempunyai tanggung jawab masing-masing. Divisi yang terdapat di perusahaan ini adalah, Marketing, Admisitrasi, HRD dan Proyek. Setiap divisi mempunyai masing-masing manager yang bertanggung jawab terhadap prestasi kerja divisi tersebut dan mempertanggung jawabkan kepada direksi.

Sebagian besar responden menjawabi setuju dan sangat setuju terhadap pernyataan tentang komitmen, kompensasi dan prestasi kerja seperti tertuang dalam kuesioner. Hanya beberapa responden yang menjawab tidak setuju. Penilaian responden yang menyatakan setuju atau sangat setuju menunjukkan bahwa responden bersikap , memiliki komitmen, 
dan menilai adil terhadap semua yang diberikan oleh perusahaan serta memiliki prestasi kerja yang relatif tinggi. Responden memilik rasa turut memiliki hadap perusahaan. Responden memiliki loyalitas yang tinggi terhadap perusahaan dan berupaya untuk bekerja lebih baik .

Koefisien regresi variabel $\left(\mathrm{X}_{1}\right)$ sebesar 0,158 dan bertanda positif menunjukkan bahwa kenaikan menyebabkan kenaikan prestasi kerja. Semakin seorang karyawan, maka prestasi kerjanya juga akan semakin tinggi. Kenaikan sebesar 1 satuan menyebabkan kenaikan prestasi kerja karyawan sebesar 0,158 (cetiris paribus). Penelitian ini mendukung hasil penelitian Nurhaida (2010) tentang pengaruh lingkungan kerja dan kerja terhadap prestasi kerja pegawai Koordinator Perguruan Tinggi Swasta (Kopertis) Wilayah I. Faktor kerja secara parsial berpengaruh signifikan terhadap prestasi kerja.

Sifat ketaatan terhadap suatu aturan atau ketentuan yang berlaku dalam organisasi atas dasar adanya kesadaran dan keinsyafan bukan adanya unsur paksaan. merupakan suatu kondisi yang tercipta dan terbentuk melalui proses dari serangkaian perilaku yang menunjukkan nilai-nilai ketaatan, kepatuhan, kesetiaan, ketenteraman, keteraturan, dan ketertiban.
Adanya kerja menjamin terpenuhinya kebutuhan terhadap perintah dan berinisiatif untuk melakukan suatu tindakan yang diperlukan seandainya tidak ada perintah.

Hal tersebut sesuai dengan Sutrisno (2010) yang menyatakan bahwa kerja dapat dilihat sebagai sesuatu yang besar manfaatnya, baik untuk kepentingan organisasi, yaitu dapat menjamin terpeliharanya tata tertib dan kelancaran pelaksanaan tugas, sehingga akan diperoleh hasil yang optimal. Sedang untuk karyawan akan diperoleh suasana kerja yang menyenangkan sehingga akan menambah semangat kerja dalam melaksanakan pekerjaaannya. Ini akan didapat jika di Perusahaan bila para karyawannya, maka setiap individu karyawan akan ikut, tetapi jika lingkungan kerjanya tidak, maka karyawan lain ikut tidak . Maka lingkungan kerja yang sangat mudah untuk menerapkan lingkungan kerja yang baik. Disebutkan bahwa yang baik adalah dapat mencerminkan besarnya tanggung jawab karyawan Perusahaan ini terhadap tugastugas yang diberikan dari perusahaan. Apabila ada maka akan memunculkan adanya gairah kerja, semangat kerja, dan dapat terwujudnya tujuan perusahaan. 
52 AGREGAT: Jurnal Ekonomi dan Bisnis

Vol. 1 No 1 Maret 2017

http://journal.uhamka.ac.id/index.php/agregat

DOI: 10.22236/agregat_vol1/is1pp38-58

Merupakan kesadaran, kemauan dan kesediaan kerja orang lain untuk taat dan tunduk terhadap semua peraturan dan norma yang berlaku baik yang tertulis maupun yang tidak tertulis sehingga tercipta kondisi yang tentram, teratur, dan tertib. Penerapan akan mengubah sikap dan perilaku karyawan dalam ujud kemauan menuju pada kerjasama dan prestasi yang lebih baik. Selanjutnya, karyawan dengan sadar mengikuti peraturan berlaku pada perusahaan. yang tinggi akan memungkinkan tujuan organisasi dapat tercapai secara efektif dan efisien.

Sementara itu, koefisien regresi variabel komitmen $\left(\mathrm{X}_{2}\right)$ juga bertanda positif. Koefisien regresi variabel komitmen sebesar 0,607. Dengan demikian kenaikan komitmen karyawan sebesar 1 satuan akan diikuti dengan kenaikan prestasi kerja karyawan sebesar 0,607 (cetiris paribus). Hal ini berarti kenaikan akan diikuti dengan kenaikan prestasi kerja. Semakin tinggi komitmen seorang karyawan, maka prestasi kerjanya akan semakin tinggi. Penelitian ini mendukung hasil penelitian Pittorino (2008) dan Khan et.al (2010). Hasil penelitian Pitorino (2008) menunjukkan komitmen organisasi yang berhubungan denngan prestasi kerja karyawan adalah komitmen afektif bersama-sama dengan komitmen normatif. Sementara itu, hasil penelitian Khan et.al (2010) menunjukkan adanya hubungan positif antara komitmen organisasi dan prestasi kerja karyawan. Dalam analisis komparatif tiga dimensi komitmen organisasi, komitmen normatif berpengaruh positif dan signifikan pada prestasi kerja karyawan.

Komitmen menunjukkan adanya suatu tindakan, dedikasi, dan kesetiaan pada janji yang telah dinyatakannya untuk memenuhi tujuan organisasi. Melaksanakan komitmen artinya menjalankan kewajiban, tanggung jawab, dan janji yang membatasi kebebasan seseorang untuk melakukan sesuatu. Komitmen menunjukkan adanya ketaatan seseorang untuk bertindak sejalan dengan janji-janjinya. Semakin tinggi derajat komitmen karyawan semakin tinggi pula prestasi kerja yang dicapainya. komitmen pekerja menunjukkan bahwa pekerja merasa ikut memilki (sense of belonging) terhadap perusahaan.

Adanya komitmen menjadikan seorang karyawan harus mendahulukan apa yang sudah dijanjikan buat 
organisasinya daripada kepentingan Indonesia. Dalam penelitian tersebut, lainnya. Adanya komitmen karyawan Trisilo Soepono menyimpulkan bahwa yang tinggi, menyebabakn perusahaan rendahnya tingkat motivasi kerja mendapatkan dampak positif seperti karyawan biasanya dapat menjadi salah meningkatkan produktivitas, kualitas, satu alasan terjadinya ketidakpuasan kerja kerja, kepuasan kerja, serta menurunnya karyawan rendahan. Kompensasi yang keterlambatan, absensi dan turnover. rendah akan menyebabkan kehilangan Komitmen karyawan memberikan motivasi para karyawan dalam kontribusi yang besar terhadap organisasi meningkatkan kepuasan kerja karyawan, karena mereka melakukan dan berperilaku bahkan tidak jarang muncul hal-hal yang untuk mencapai tujuan organisasi. Pekerja tidak ekonomis akan menurunkan yang memiliki komitmen terhadap motivasi kerjanya.

perusahaan, akan mereka senang menjadi

Kompensasi merupakan dorongan karyawan pada perusahaan tersebut dan utama seseorang menjadi karyawan. berniat untuk melakukan apa yang baik Apabila suatu perusahaan tidak mampu bagi organisasi.

Koefisien regresi variabel kompensasi (X3) bertanda positif. Koefisien regresi variabel kompensasi sebesar 0,360. Hal ini berarti kenaikan kompensasi sebesar 1 satuan menyebabkan kenaikan prestasi kerja karyawan sebesar 0,360 (cetiris paribus). Kenaikan kompensasi menyebabkan kenaikan prestasi kerja karyawan. Semakin tinggi kompensasi yang diterima karyawan, semakin tinggi pula prestasi kerjanya. Penelitian ini mengembangkan dan menerapkan suatu sistem kompensasi yang memuaskan, maka perusahaan bukan hanya akan kehilangan tenaga-tenaga terampil dan berkemampuan tinggi. Besarnya kompensasi sangat berpengaruh terhadap semangat dan kegairahan kerja karyawan. Pemberian kompensasi dapat meningkatkan prestasi kerja dan kepuasan kerja karyawan. Sistem kompensasi itu merupakan instrumen yang ampuh untuk berbagai kepentingan. Menurut Al Fajar, mendukung hasil penelitian Trisilo Siti dan Tri Heru (2010) dalam Soepono (2007) tentang pengaruh menghadapi tantangan dalam rangka motivasi kerja, kepuasan kerja dan persaingan di era global, kompensasi bagi lingkungan kerja terhadap prestasi kerja karyawan adalah sebagai kunci dalam karyawan PT.Reasuransi Nasional mengelola sumber daya manusia yang 
54 AGREGAT: Jurnal Ekonomi dan Bisnis

Vol. 1 No 1 Maret 2017

http://journal.uhamka.ac.id/index.php/agregat

DOI: 10.22236/agregat_vol1/is1pp38-58

efektif, dimana perusahaan mengakui maka akan terjadi peningkatan daya tarik bahwa dengan kompensasi perusahaan pelamar kerja yang potensial bagi tidak hanya menarik pelamar kerja yang perusahaan, timbulnya motivasi dan rasa potensial, memotivasi dan senang bekerja di perusahaan, dapat lebih mempertahankan karyawan, tetapi juga meningkatkan daya saing dan dapat mempertinggi daya saing, memperpanjang kelangsungan hidup di kelangsungan hidup, dan profitabilitas perusahaan.

perusahaan. Hal ini menunjukkan bahwa

Dengan demikian, setiap perusahaan kompensasi merupakan salah satu faktor penting yang dapat mendorong untuk harus dapat menetapkan kompensasi yang memberikan balas jasa terhadap paling tepat sehingga dapat menopang perusahaan tempat karyawan tersebut bekerja.

Adanya kompensasi yang memadai dapat membuat karyawan termotivasi untuk bekerja dengan baik, mencapai prestasi seperti yang diharapkan dan dapat meningkatkan tingkat kepuasan karyawan. Kompensasi berperan penting karena dapat mempengaruhi kesejahteraan dan kemakmuran masyarakat luas, semakin tinggi tingkat kompensasi suatu perusahaan akan semakin makmur dan sejahtera karyawan perusahaan tersebut. mencapai tujuan perusahaan secara lebih efektif dan efisien. Perusahaan tidak dapat dilihat sebagai bagian yang berdiri sendiri, tetapi harus dilihat sebagai satu kesatuan yang tangguh dan harus merupakan sumber kekuatan yang ada , dan terdiri dari kekuatan seluruh karyawan yang ada, yang dapat didayagunakan dalam memajukan perusahaan.

\section{SIMPULAN}

Berdasar hasil analisis dan pembahasan diatas dapat diambil beberapa simpulan berikut: Komitmen berpengaruh Kompensasi berperan penting dalam positif dan signifikan terhadap prestasi meningkatkan prestasi kerja dan kepuasan kerja karyawan pada PT. Somit Karsa kerja karyawan. Ini sesuai dengan Trinergi; Kompensasi berpengaruh positif pendapat Al Fajar, Siti dan Tri Heru dan signifikan terhadap prestasi kerja (2010) bahwa dengan pemberian karyawan pada PT. Somit Karsa Trinergi; kebijakan kompensasi bagi karyawan Komitmen dan kompensasi secara 
bersama-sama berpengaruh positif dan Kompensasi berperan penting dalam signifikan terhadap prestasi kerja meningkatkan prestasi kerja dan kepuasan karyawan PT. Somit Karsa Trinergi: Nilai kerja karyawan. Pemberian kompensasi R2 sebesar 0,843 menunjukkan bahwa dapat meningkatkan prestasi kerja dan proporsi variasi pada variabel prestasi kepuasan kerja karyawan. Sistem kerja dapat dijelaskan oleh variasi kompensasi itu merupakan instrumen variabel, komitmen dan kompensasi yang ampuh untuk berbagai kepentingan; adalah sebesar 84,3 persen. Sedangkan Prestasi kerja di perusahaan di pengaruhi sisanya sebesar 15,7 persen dijelaskan oleh faktor, komitmen, dan kompensasi. oleh variabel-variabel di luar model.

Implikasi dari penelitian ini sebagai berikut: Kenaikan menyebabkan Kemauan, kesadaran kerja, dan perilaku karyawan serta penghargaan yang diterima dalam ujud kompensasi sangat kenaikan prestasi kerja karyawan. menentukan bagi tinggi rendahnya Adanya menunjukkan bahwa karyawan dengan sadar mengikuti peraturan berlaku pada perusahaan sehingga memungkinkan bagi tercapainya tujuan organisasi termasuk tujuan peningkatan peningkatan prestasi kerja karyawan; Adanya komitmen menyebabkan karyawan mendahulukan kesediaan yang sudah dijanjikan buat organisasinya daripada kepentingan lainnya. Komitmen karyawan yang tinggi, menyebabkan peningkatan kepuasan kerja, serta menurunnya keterlambatan, absensi dan turnover sehingga prestasi kerja karyawan meningkat; Kompensasi yang memadai dapat membuat karyawan termotivasi untuk bekerja dengan baik, mencapai prestasi seperti yang diharapkan dan dapat prestasi kerja karyawan.

\section{REFERENSI}

Al Fajar, S. dan Tri, H. (2010). Management Sumber Daya manusia Sebagai dasar Meraih Keunggulan Bersaing. Yogyakarta: Penerbit: Unit Penerbit dan Percetakan STIM YKPN.

Alfian, Y. (2007). Analisis Pengaruh Disilpin Kerja, Kepuasan kerja dan Motivasi kerja terhadap Peningkatan Prestasi kerja Karyawan pada Kantor Wilayah Utama Perum Pengadaian Jakarta. Jakarta: Tesis.

Armstrong, M. (2006). A Handbook of Human Resource Management meningkatkan tingkat kepuasan karyawan. 
56 AGREGAT: Jurnal Ekonomi dan Bisnis

Vol. 1 No 1 Maret 2017

http://journal.uhamka.ac.id/index.php/agregat

DOI: 10.22236/agregat_vol1/is1pp38-58

Practice (10th ed.). London:

Kogan Page.

Cooper dan Robertson. (2006). The

Psychology of Personel

Selection, A quality Approach

London. London: SAGE

Publications, Inc.

George, JM \& Jones.G. (2006).

Organizational Behaviour, 5th

Edition. New Jersey: Prentice

Hall International Inc.

Getol, G. (2010). Management Miracle

Series Good Leadership VS Bad

Leadership. Jakarta: Penerbit PT

Elex Media Komputindo, 1 st ed.

Ghozali, I. (2001). Aplikasi Analisis

Mutivariate dengan SPSS.

Semarang: Badan Penerbit

Universitas Diponegoro.

Handari, N. (2008). Manajemen Sumber

Daya Manusia Untuk Bisnis

Kompetitif. Yogyakarta: Gadjah

mada University Press.

Jones J.J, dan Walters, D.L. (2008).

Manajemen Sumber Daya dalam

Pendidikan. Yogyakarta: Q

Media.

Khan, M.R. Ziauddin, F.A.J dan M. I.

Ramay. (2010). The Impacts of

Organizational Commitment on
Employee Job Performance,

European Journal of Social

Sciences, 15 (3). Diunduh dari

www.eurojournals.com

Mangkunegara, A. P. (2009). Manajemen

Sumber daya Manusia

Perusahaan. Bandung: PT

Remaja Rosdakarya.

Muniarti, D. (2006). Analisis Hubungan Kompensasi, Pengembangan Karier, Motivasi dengan Prestasi kerja (Kasus Pada Karyawan UPN "Veteran" Jakarta). Jakarta: Tesis UPN.

Nurhaida. (2010). Pengaruh Lingkungan Kerja dan Kerja Terhadap Prestasi Kerja Pegawai Koordinasi Perguruan Tinggi Swasta Wilayah I Nanggroe Aceh Darussalam Sumatera Utara. Medan: Tesis, Universitas Sumatera Utara. Diunduh dari http://repository.usu.ac.id/bitstrea m/123456789/204945.pdf

Koesmono, H. Teman. (2007). Pengaruh Kepemimpinan dan Tuntutan Tugas Terhadap

Komitmen Organisasi Dengan Variabel Moderasi Motivasi Perawat Rumah Sakit Swasta 
Surabaya. Surabaya: Jurnal Siagian, S. (2008). Managemen Sumber

Manajemen dan kewirausahaan

Vol 9. No. 1 Maret: 30-40.

Robbins \& Judge. (2007). Perilaku

Organisasi, Edition 12. Jakarta:

Salemba Empat.

Rudiyanto, M. (2010). Analisis Pengaruh

Kompensasi,

Gaya

Kepemimpinan dan Kondisi

Kerja terhadap Kepuasan Kerja

Pegawai negeri Sipil Pada

Direktorat Penilaian Kekayaan

Negara. Jakarta: Tesis.

Pitorino. (2008). Hubungan Antara

Budaya Organisasi, Komitmen

Organisasi dan Prestasi kerja

Karyawan di Eskom Afrika

Selatan, Afrika Selatan: Rhodes

University, Thesis.

Sariyathi. (2007). Prestasi Kerja

Karyawan, suatu kajian teori.

Fakultas Ekonomi Unud Bali,

$\mathrm{Http} / /$

ejournal.unud.ac.id/abstract/sariy ati/pdf..

Sihotang. (2007). Manajemen Sumber

Daya Manusia. Jakarta: PT Pradnya Pramita.

Simamora, H. (2006). Manajemen Sumber

Daya Manusia, ed 2. Yogyakarta:

Penerbit STIE YPKN.
Daya Manusia. Jakarta: PT

Bumi Aksara, 16 st.

Soepono, T. (2007). Analisis Pengaruh Motivasi Kerja, Kepuasan Kerja dan Lingkungan Kerja Terhadapa Prestasi kerja Karyawan PT. Reasuransi Nasional Indonesia. Tesis.

Suyanto dan Yulistyawan. (2007). Otomatisasi Sistem Pengendali Berbasis PLC Padd Mesin Vacuum Metalizer Untuk Proses Coating (Studi Kauss Astra otoparts, TBK). Gematek, Jurnal Teknik Komputer, Vol. 9 No.2.

Sutrisno, E. (2010). Manajemen Sumber Daya Manusia, Jakarta: Kencana Prenada Media Group, 2 ed.

Tabassi, A.A. dan A.H. Abu Bakar. (2009). Training, motivation, and performance: The case of human resource management in construction projects in Mashhad, Iran, International Journal of Project Management, 27: 471-480. Diunduh dari: http://www.sciencedirect.com/sci ence/article/pii/S0263786308001 130 
58 AGREGAT: Jurnal Ekonomi dan Bisnis

Vol. 1 No 1 Maret 2017

http://journal.uhamka.ac.id/index.php/agregat

DOI: 10.22236/agregat_vol1/is1pp38-58

Triton. (2010). Managemen Sumber Daya

manusia Perpektif Partnership

dan Kolektivitas. Yogyakarta:

Penerbit Oryza. 